\title{
INKUNABULA HIERONIMI CAPIDURI CIVIS PARENTINI GEORGII VALLAE DISCIPULI IN RHETORICA CICERONIS AD HERENNIUM COMMENTARIUM (VENETIIS, 1490.)
}

Dr. sc. Nikola Cesarik

Hrvatska akademija znanosti i umjetnosti

Zavod za povijesne i društvene znanosti u Rijeci

Ružićeva 5, HR - 51000 Rijeka

ncesarik@gmail.com

\author{
UDK 726(497.561) \\ Pregledni članak \\ Primljeno: 7. 11. 2019. \\ Prihvaćeno: 27. 1. 2020. \\ DOI: $10.21857 / y d k x 2 c w 149$
}

U knjižnici Zavoda za povijesne $i$ društvene znanosti HAZU u Rijeci čuva se jedna tiskovina za koju se drži da predstavlja inkunabulu tiskanu 1490. u Veneciji s komentarima Porečanina Girolama Capidura (Hieronymus Capidurus Parentinus)o djelu Rhetorica ad Herennium. No, zbog činjenice da su u hrvatskoj stručnoj literaturi prisutni podatci da je Girolamo Capiduro tiskao navedene komentare tek 1550. godine, javila se i sumnja je li tiskovina iz riječkog Zavoda doista inkunabula. U radu se preispituje činjenično stanje te se dokazuje da je navedena tiskovina doista izdana u Veneciji 1490. godine te da je riječ ne samo o jedinoj inkunabuli koja se čuva u Zavodu u Rijeci već i o jedinom poznatom primjerku te tiskovine koji se čuva na hrvatskom tlu. Nadalje se raspravlja o identitetu autora inkunabule, jer sve činjenice upućuju na zaključak da je Girolamo Capiduro zapravo pseudonim Giorgia Valle, humanista rodom iz Piacenze.

Ključne riječi: inkunabula; Girolamo Capiduro; Hieronymus Capidurus Parentinus; Rhetorica ad Herennium; Ciceron; pseudonim; Giorgio Valla.

\section{Uvod}

U knjižnici Zavoda za povijesne i društvene znanosti HAZU u Rijeci, među ostalim rijetkim izdanjima, čuva se i jedna meko uvezana tiskovina na čijim je koricama rukopisom novijeg datuma (19. ili 20. stoljeće) ispisan naslov na talijanskom jeziku: incunabula: Commentario alla Retorica di Cicerone di Girolamo 
Capiduro parentino, 1490 (slika 1). ${ }^{1}$ Sudeći dakle prema samom naslovu, riječ je o inkunabuli tiskanoj 1490. godine u kojoj je određeni Parentinac, odnosno Porečanin, Girolamo Capiduro, objavio svoje komentare o djelu Rhetorica ad Herennium koje se tradicijski pripisivalo nikom drugom negoli čuvenom govorniku Marku Tuliju Ciceronu. ${ }^{2}$ Za spomenutu sam tiskovinu saznao od knjižničarke Akademijina Zavoda u Rijeci, kolegice Hane Lencović, koja mi je tada napomenula i zanimljiv podatak da zapravo nije sigurno radi li se stvarno o inkunabuli jer postoje određene indicije da je knjiga ipak tiskana nešto kasnije. ${ }^{3}$

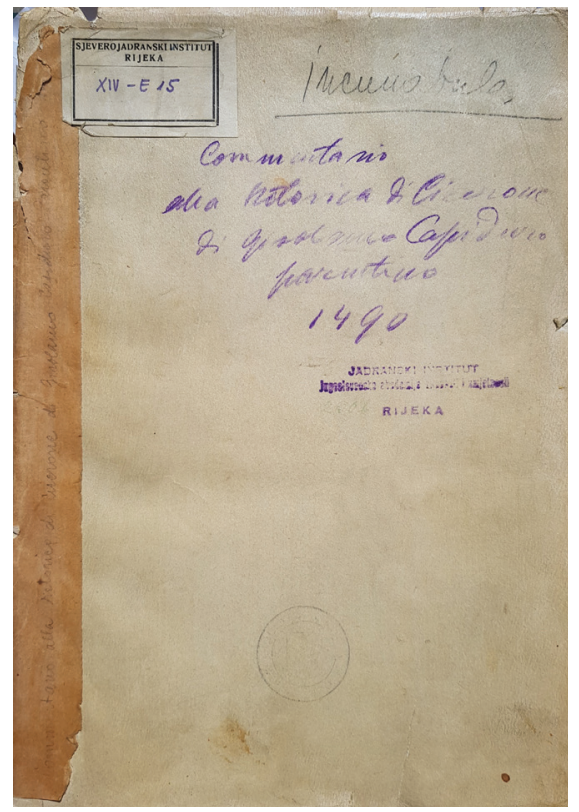

Slika 1. Korice inkunabule iz Zavoda za povijesne i društvene znanosti HAZU u Rijeci (snimio N. Cesarik)

1 Uz pečat Jadranskog instituta JAZU u Rijeci (sadašnji Zavod za povijesne i društvene znanosti HAZU u Rijeci) na koricama tiskovine nalazi se i pečat nekadašnje Gradske knjižnice u Poreču (Biblioteca civica Parenzo). Knjiga je zavedena pod brojem 2907 u inventarnoj knjizi knjižnice Zavoda za povijesne i društvene znanosti HAZU u Rijeci, gdje je zapisano da je inventirana 1. lipnja 1954. te nabavljena od Kotarskog narodnog odbora Poreč.

2 O djelu Rhetorica ad Herennium te posebice njegovu autoru, usp. H. CAPLAN, [Cicero] ad C. Herennium de ratione dicendi (Rhetorica ad Herennium), Loeb Classical Library 403, Cambridge, MA: Harvard University Press, 1954., str. vii-xliv; T. NüssleIn, Rhetorica ad Herennium: Lateinisch-deutsch, Düsseldorf: Artemis \& Winkler, 1998., str. 328-330. Iako se djelo tradicionalno pripisivalo Ciceronu, ono se danas pripisuje nepoznatom autoru, koji se katkada naziva i Pseudo-Ciceron.

3 Ovom prilikom najiskrenije zahvaljujem kolegici Hani Lencović na susretljivosti i svesrdnoj pomoći oko naslovne tematike. 
Problemi sjevernog Jadrana 18 (2020), str. 11-24

Nikola Cesarik Inkunabula Hieronimi Capiduri civis Parentini Georgii Vallae discipuli in Rhetorica Ciceronis ad Herennium...

S obzirom na to da bi - ako je doista riječ o inkunabuli - navedena tiskovina bila jedina inkunabula koja se čuva u Zavodu u Rijeci, ali i zbog činjenice da ona sadrži čuveno antičko djelo o umijeću govorništva, itekako je valjalo istražiti što se zapravo krije iza naslova koji mi se nenadano našao u rukama. I doista, već pri preliminarnoj potrazi uočio sam koja se kontroverza krije iza naslova tiskovine, jer za ime Girolama Capidura pronašao sam sljedeće podatke:

1. „CAPIDURO, Girolamo, filolog i latinist (Poreč, druga pol. XV st. - ?, prva pol. XVI st.). Malo se zna o njegovu životu, a jedva nešto o njegovu književnom djelu. U Storia letteraria di Trieste e dell'Istria (Trst 1924) Baccio Ziliotto navodi da je C. bio učenik talijanskog humanista Lorenza Valle, što se vidi iz njegova jedinoga djela dospjelog do nas Comentarii in Rhetoricam Ciceronis ad Herennium (Mleci 1550). Komentirajući i veličajući Cicerona, izlaže svoje nazore o kreposti i etici s gledišta suprotnih aristotelskoj filozofiji." 4

2. „Capiduro, Girolamo, filolog (Poreč, druga pol. XV.st. - ?, prva pol. XVI. st.). O njegovu se životu ne zna gotovo ništa. Mladost je vjerojatno proveo $u$ Poreču, a školovao se u Italiji. Baccio Ziliotto navodi da je bio učenik talijanskog humanista Lorenza Valle (umro 1457), od kojega je preuzeo zanimanje za Cicerona i humanizam uopće. Sačuvano je samo jedno njegovo djelo, Comentarii in Rhetoricam Ciceronis ad Herennium, tiskano u Veneciji 1550. U njemu razlaže svoja gledišta o krjeposti i etici, suprotna aristotelovskoj filozofiji." ${ }^{5}$

\section{Vrijeme i mjesto tiskanja}

Dakle, ako je vjerovati navodima iz Hrvatskog biografskog leksikona i Istarske enciklopedije, Girolamo Capiduro stvarno je tiskao komentare o djelu Rhetorica ad Herennium, ali ne 1490., kako stoji na koricama primjerka iz riječkog Zavoda, već tek 1550., prema čemu bi se njegovo stvaralaštvo ipak datiralo u 16., a ne 15. stoljeće. S obzirom na to da na primjerku iz riječkog Zavoda nema naslovnice (što je zapravo i karakteristika inkunabula) niti su na prvoj stranici navedeni datum i mjesto tiskanja, postalo mi je jasno zašto je ranije postojala sumnja da je riječ o tiskovini iz 15. stoljeća. No, daljnjim pretragama o komentarima Girolama Capidura o djelu Rhetorica ad Herennium, napose u tražilici sustava umreženih knjižnica WorldCat, uočio sam da u nekoliko knjižnica doista postoje primjerci

Hrvatski biografski leksikon, sv. 2, Zagreb: Jugoslavenski leksikografski zavod „Miroslav Krleža”, 1989., str. 570.

5 Istarska enciklopedija, M. BertošA, R. MatıAAšıć (ur.), Zagreb: Leksikografski zavod „Miroslav Krleža", 2005., str. 127. 
Capidurova djela iz 1490. godine, ${ }^{6}$ što je otvorilo sumnju u ispravnost navoda o liku Girolama Capidura koje se mogu pronaći u hrvatskoj stručnoj literaturi.

Sumnja $\mathrm{u}$ ispravnost tih navoda postala je još jačom kada sam uočio da se u sredini primjerka iz riječkog Zavoda nalazi papir s naslovom i inventarnim brojem, na kojem je za godinu i mjesto tiskanja kemijskom olovkom prvotno bilo navedeno „Venetiis 1555”, da bi se naknadno, običnom olovkom, prekrižila 1555. te se pokraj nje navela 1490. godina. Da bi stvar bila upečatljivija, pokraj godine 1490. nalaze se i dvije kvačice naznačene kemijskom olovkom crvene boje (slika 2), na temelju čega sam stekao dojam da je netko u određenom trenutku provjerom utvrdio da je ovdje riječ o tiskovini iz 15. stoljeća.

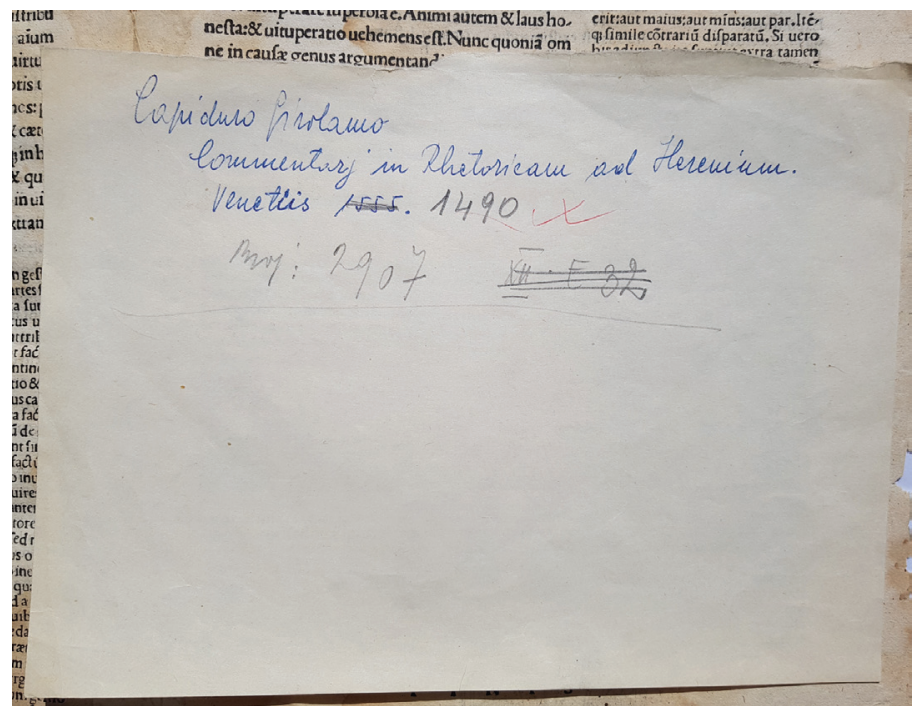

Slika 2. Umetnuti papir s natuknicom o autoru i naslovu te mjestu i vremenu tiskanja knjige (snimio N. Cesarik)

Budući da sam sve više bio siguran da se radi o jedinoj inkunabuli iz knjižnice Akademijina Zavoda u Rijeci, nastavio sam s pretraživanjem te sam - došavši do samog kraja knjige - pronašao i podatak o mjestu i vremenu tiskanja knjige. Ključni dokaz nalazi se pri dnu pretposljednje stranice, u kolofonu s podatcima: ... Gulielmus Tridinensis cognome(n)to Anima mia : cuius opera hoc opusculu(m)

6 Na mrežnoj stranici worldcat.org, ako se u tražilicu upiše ime „Girolamo Capiduro" ili „Hieronymus Capidurus" te među ponuđenim godinama odredi izdanje iz 1490. godine, dobivaju se podatci o knjižnicama koje posjeduju tu tiskovinu. 
Venetiis fuit descriptum principe Augustino Barbadico primo calendas Septemb(ris) Mcccclxxxx (slika 3). Dakle, knjiga je tiskana 31. kolovoza (ili 1. rujna) 1490. u Veneciji ${ }^{7}$ kod tiskara Guglielma iz Trina (Gulielmus Tridinensis).

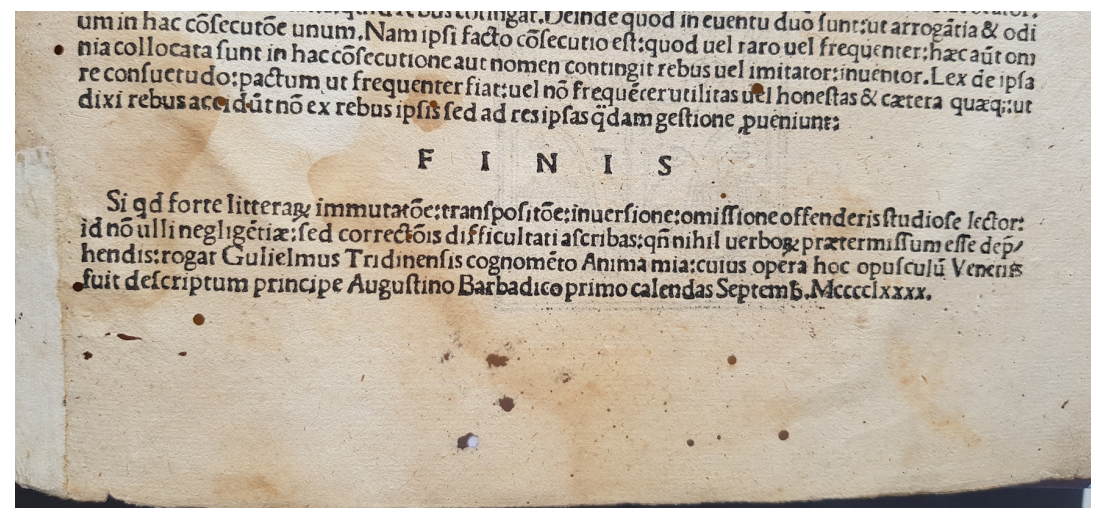

Slika 3. Kolofon s podatcima o mjestu i vremenu tiskanja inkunabule (snimio N. Cesarik)

Na sljedećoj, ujedno i posljednjoj, stranici nalazi se i tiskarski znak Guglielma iz Trina (slika 4). Središnji je njegov motiv drvo hrasta s jasno naznačenim žirovima, dok je ispod njegove krošnje svezana vrpca na čijim krakovima stoje slova P i C. Ispod vrpce su otisnuta slova G i T koja predstavljaju inicijale tiskara (Gulielmus Tridinensis). Drvo hrasta uokvireno je trakom koja formira oblik šti-

7 U literaturi se mogu pronaći podatci kako je knjiga tiskana 31. kolovoza ili 1. rujna 1490. (više o tome na: https://data.cerl.org/istc/ic00682000). Naime, konstrukcija primo calendas Septembris nije karakteristična za određivanje datuma u rimskom kalendaru, u kojem se dan prije septembarskih kalendi (31. kolovoza) označavao izrazom pridie Kalendas Septembris, dok je prvi dan rujna označavan kao Kalendis Septembris. S obzirom na rimski inkluzivni način računanja, sam dan prije kalenda, nona ili ida (Kalendae, Nonae, Idus) određenog mjeseca zapravo bi bio "drugi dan prije kalenda, nona ili ida", no za taj se dan uglavnom koristio termin pridie (usp. A. K. Michels, The Calendar of the Roman Republic, Princeton, New Jersey: Princeton University Press, 1967., str. 22). Premda bi zbog rimskog načina brojenja „prvi dan prije kalendi” teoretski bile same kalende, valja odmah naglasiti da se prvi dan u mjesecu nikada nije referirao na taj način, jer za taj se dan uvijek koristila samo riječ Kalendis (primjerice: Kalendis Septembris prvi dan rujna). Prema tomu, s obzirom na to da konstrukcija primo calendas Septembris nije u skladu s rimskim načinom određivanja dana u mjesecu, teško je sa sigurnošću reći je li se pod tom konstrukcijom mislilo na 31. kolovoza (dan prije septembarskih kalendi po suvremenom načinu računanja) ili 1. rujna (prvi dan septembra) 1490. godine. O rimskom načinu računanja određenih dana u mjesecu, pregledno kod: C. ВЕСК, Syntax of the Latin Language, chiefly from the German of C. G. Zumpt, 2nd ed., Boston: J. Munroe and company, 1844., str. 175-178. Detaljan pregled razvoja rimskog kalendara u novije vrijeme donosi J. RüPKE, The Roman Calendar from Numa to Constantine: Time, History and the Fasti, Wiley-Blackwell, 2011. 
ta na čijim krakovima vijore vrpce koje pridržavaju dvije golubice prikazane $u$ gornjim uglovima, dok su u donjim uglovima prikazana dva zeca na stiliziranoj livadi. $^{8}$

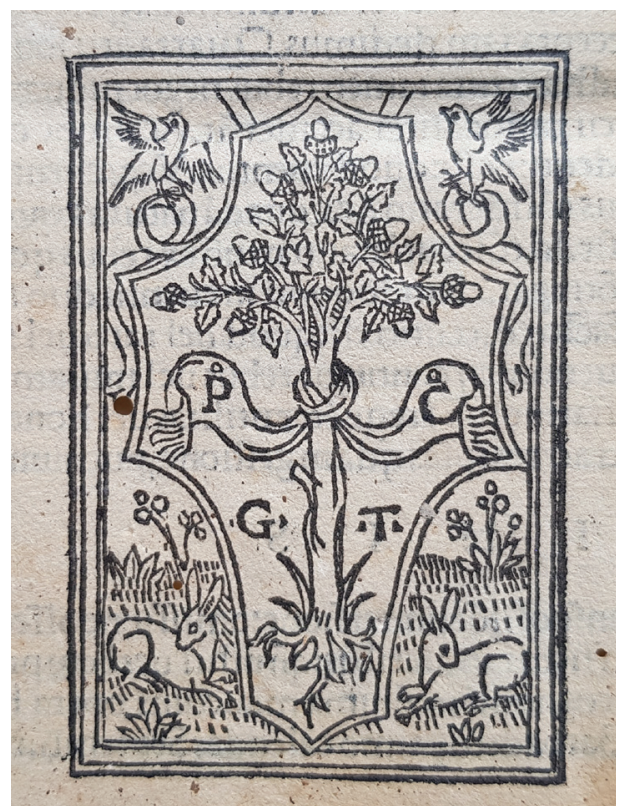

Slika 4. Tiskarski znak Guglielma iz Trina (snimio N. Cesarik)

Nadalje, zahvaljujući sve raširenijem procesu digitalizacije stare rukopisne i tiskarske građe, došao sam i do spoznaje o postojanju javno dostupne digitalne kopije Capidurova djela koje se čuva u Bavarskoj državnoj knjižnici (Bayerische Staatsbibliothek) u Münchenu. ${ }^{9} \mathrm{~S}$ obzirom na to da je navedeni primjerak identičan onomu iz Akademijina Zavoda u Rijeci, preliminarni pregled činjeničnog stanja odbacio je svaku sumnju u to da je riječ o inkunabuli.

Knjiga je dakle bez sumnje tiskana 1490. u Veneciji, prema čemu je jasno da valja korigirati podatke iz Hrvatskog biografskog leksikona i Istarske enciklopedije te da stvaralaštvo dotičnoga Girolama Capidura valja iz 16. premjestiti na sam kraj 15. stoljeća. Uz to, s obzirom na to da navedene tiskovine nema u Badalićevu

8 Znak je u osnovnim crticama opisao F. LetTIERI, Codicum saeculo XV impressorum qui in Regia bibliotheca borbonica adservantur catalogus ordine alphabetico digestus notisque bibliographicis illustratus, tom. 1, Neapoli, 1828., str. 183.

9 Signatura: BSB-Ink A-822. Dostupno na: opacplus.bsb-muenchen.de/title/BV035317537. 
Problemi sjevernog Jadrana 18 (2020), str. 11-24

Nikola Cesarik Inkunabula Hieronimi Capiduri civis Parentini Georgii Vallae discipuli in Rhetorica Ciceronis ad Herennium...

popisu inkunabula u Hrvatskoj, ${ }^{10}$ za sada se čini da je ovdje riječ o jedinom poznatom primjerku tog izdanja na hrvatskom tlu. ${ }^{11}$

Na pitanje zašto se $u$ hrvatskoj stručnoj literaturi potkrao pogrešan podatak o vremenu prvog tiskanja Capidurova djela, odgovor se dobiva iz samih citiranih djela u Hrvatskom biografskom leksikonu. Tako primjerice Bartolomeo Vergottin u svojem Kratkom eseju o staroj i modernoj povijesti Poreča navodi izdanje iz 1550., ${ }^{12}$ dok čuveni Barbanac Pietro Stancovich (iliti Petar Stanković), u svojoj poznatoj Biografiji istaknutih Istrana, navodi izdanje iz 1555. godine. ${ }^{13}$ Očito je dakle kako ni Vergottin ni Stancovich nisu znali za izdanje iz 1490., što je i uzrokovalo naknadne pogreške vezane za lik Girolama Capidura prisutne u hrvatskoj relevantnoj literaturi.

\section{Girolamo Capiduro = Giorgio Valla}

No, daljnje je istraživanje otkrilo kako greška u hrvatskoj literaturi nije vezana samo za dataciju tiskanja Capidurova djela već praktički i za sav ostali sadržaj naveden pod njegovim imenom. Naime, osim netočnog podatka o godini prvog izdanja jedinoga njegova djela, u Hrvatskom biografskom leksikonu i Istarskoj enciklopediji prenesen je i podatak Baccia Ziliotta da je Girolamo Capiduro bio učenik Lorenza Valle, ${ }^{14}$ čuvenog talijanskog humanista koji je preminuo 1457. godine - dakle pune 33 godine prije tiskanja prvog izdanja Capidurovih komentara o djelu Rhetorica ad Herennium, odnosno gotovo stotinu godina prije izdanja spomenutog u navedenim enciklopedijskim djelima.

10 J. BADAlić, Inkunabule u Narodnoj Republici Hrvatskoj, Zagreb: Jugoslavenska akademija znanosti i umjetnosti, 1952.

11 Najpotpuniji pregled svih poznatih primjeraka Capidurovih komentara o djelu Rhetorica ad Herennium tiskanih 1490., nalazi se na mrežnom katalogu ISTC (Incunabula Short Title Catalogue) u sustavu The British Library (dostupno na: https://data.cerl.org/istc/ic00682000), a na istom su mjestu navedeni i svi relevantni katalozi u kojima je spomenuta ta inkunabula. Najbliži primjerak nama nalazi se u Ljubljani (Narodna in univerzitetna knjižnica), usp. A. GspaN, J. BADALIĆ, Inkunabule v Sloveniji, Ljubljana: Slovenska akademija znanosti in umetnosti, 1957., str. 131, br. 183.

12 B. Vergottin, Breve saggio d' istoria antica e moderna della città di Parenzo nell' Istria, Venezia, 1796., str. 84.

13 P. Stancovich, Biografia degli uomini distinti dell'Istria, tom. 2, Trieste, 1829., str. 100.

14 B. Zıьıотто, Storia letteraria di Trieste e dell' Istria, Trieste, 1924., str. 25. Zanimljivo je spomenuti kako je upravo Lorenzo Valla bio prvi koji je izrazio sumnju u Ciceronovo autorstvo djela Rhetorica ad Herennium; usp. H. CAPLAN (nav. dj. u bilj. 2), str. ix. 
Međutim, učitelj Girolama Capidura nije bio Lorenzo ${ }^{15}$ već Giorgio Valla humanist iz Piacenze koji je ostao poznat po tiskanju brojnih edicija i prijevoda djela antičkih pisaca krajem 15. stoljeća. ${ }^{16}$ To je naime jasno iz samog predgovora Capidurovih komentara s riječima posvete: Hieronymus Capidurus Parentinus, discipulus clarissimi viri Georgii Vallae, Dominico Capiduro artium ac medicinae doctori praestantissimo s. dicit (slika 5).

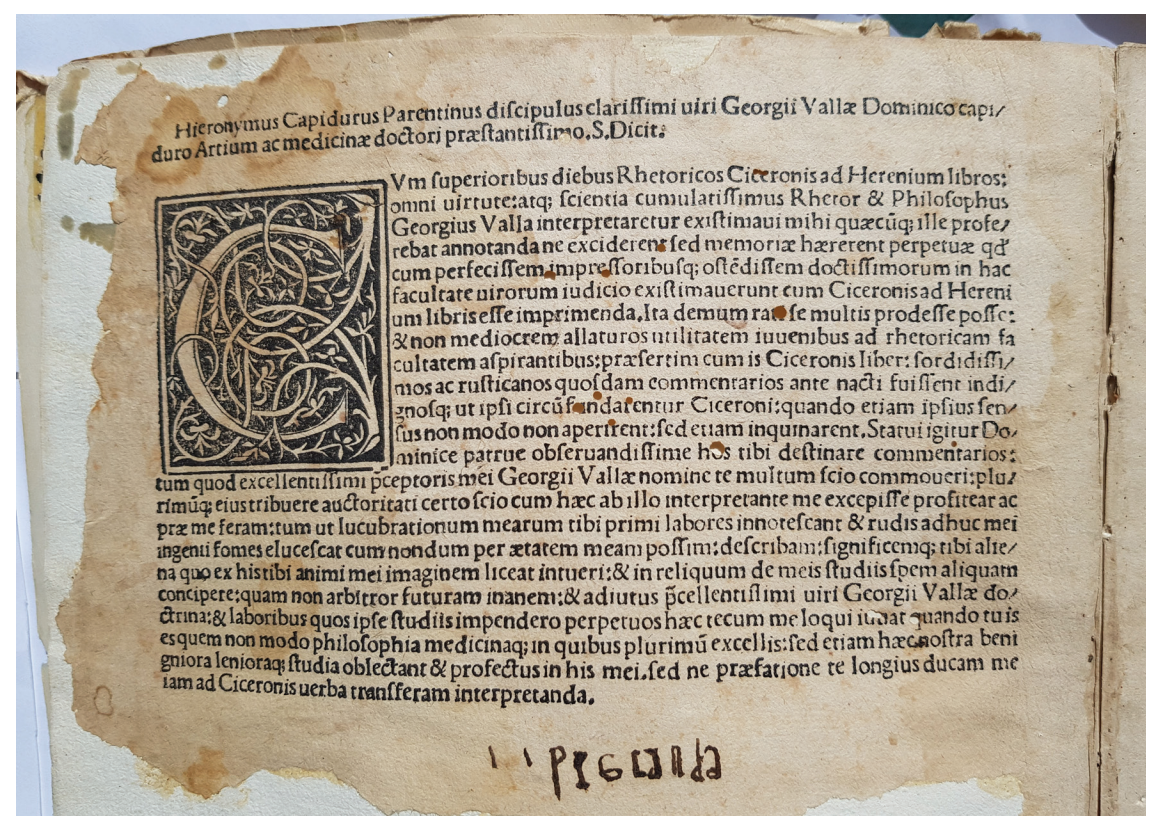

Slika 5. Predgovor inkunabule s posvetom Dominiku Kapiduru (snimio N. Cesarik)

Dakle, Hijeronim Kapidur (lat. Hieronymus Capidurus, tal. Girolamo Capiduro), rodom iz Poreča (Parentinus), učenik preslavnog muža Giorgia Valle (lat. Georgius Valla), posvetio je svoje djelo Dominiku Kapiduru, uglednom doktoru umijećá i medicine, za kojega u jednoj od naknadnih rečenica saznajemo da je

15 O Lorenzu Valli (s ostalom relevantnom literaturom) usp. najnovije: L. NAUTA, Lorenzo Valla, u: E. N. Zalta (ur.), The Stanford Encyclopedia of Philosophy, Summer 2017 Edition, (dostupno na: https://plato.stanford.edu/archives/sum2017/entries/lorenzo-valla).

16 O liku i djelu Giorgia Valle, usp. najnovije: A. A. RAschiERI, Giorgio Valla, Editor and Translator of Ancient Scientific Texts, u: P. Otmos (ur.), Greek Science in the Long Run: Essays on the Greek Scientific Tradition (4th c. BCE-17th c. CE), Newcastle upon Tyne: Cambridge Scholars Publishing, 2012., str. 127-150. 
Hijeronimov stric (Statui igitur, Dominice patrue observandissime, hos tibi destinare commentarios). Da je Girolamo Capiduro učenik Giorgia Valle, jasno je i po samom naslovu navedenog djela, koji se nalazi na sljedećoj stranici knjige (zapravo prvoj stranici samih Capidurovih komentara uz djelo Rhetorica ad Herennium, koje on pripisuje Ciceronu): Hieronimi Capiduri civis Parentini Georgii Vallae discipuli in Rhetorica Ciceronis ad Herennium commentarium (slika 6).

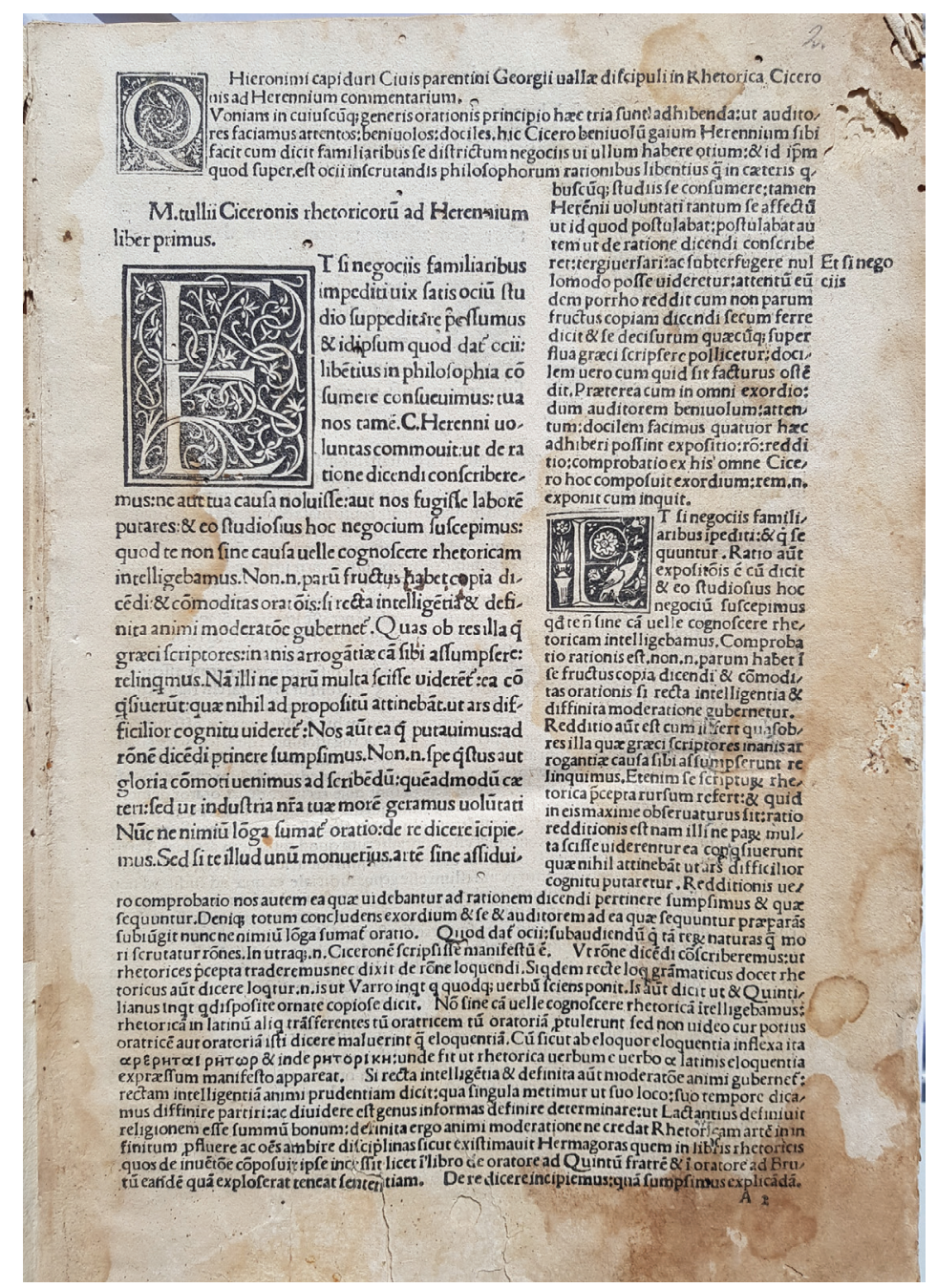

Slika 6. Prva stranica Capidurovih komentara o djelu Rhetorica ad Herennium (snimio N. Cesarik) 
Međutim, podatak da je dotični Girolamo Capiduro bio učenik Giorgia, a ne Lorenza Valle i ne iznenađuje toliko ako ga usporedimo s činjenicom da je ime tog (navodnog) Porečanina - po svemu sudeći - samo pseudonim Giorgia Valle iza kojega se taj uvaženi naučenjak iz određenog razloga odlučio sakriti.

Taj je podatak prisutan u stručnoj literaturi još od 18. stoljeća, odnosno od samog trenutka kada se u literaturi prvi put i spomenulo izdanje s komentarima o djelu Rhetorica ad Herennium iz 1490. godine. Tako se prvi podatak o toj tiskovini pojavio u djelu Bibliotheca scriptorum Mediolanensium Philippa Argelatija, ${ }^{17}$ a nedugo potom i u pismu isusovca Francesca Antonija Zaccarije, upućenom Giovanniju Crisostomu Trombelliju te objavljenom 1751. godine u 45. svesku publikacije Raccolta d'opuscoli scientifici e filologici (u ranijim izdanjima često referirano kao Raccolta Calogeriana).${ }^{18}$ Zanimljivo je spomenuti kako Zaccaria tom prilikom uopće ne spominje Girolama Capidura već kao autora komentara o djelu Rhetorica ad Herennium spominje samo Giorgia Vallu, dok Argelati navodi kako je potonji objavio to djelo pod imenom Hijeronima Kapidura (Hieronymus Capidurus). Njihovo mišljenje prihvaća i Cristoforo Poggiali, ${ }^{19}$ a nešto kasnije i Vincenzo Lancetti, koji ime Girolama Capidura pridodaje svom popisu pseudonima poznatih pisaca, ${ }^{20}$ odnosno u tom slučaju kao pseudonim samog Giorgia Valle.

No nijedan od navedenih autora nije obrazložio zašto bi ime Hijeronima Kapidura zapravo bio pseudonim Giorgia Valle. Na to prvenstveno upućuje činjenica kako se ime Hieronymus Capidurus ne spominje ni u jednom drugom djelu, dok je iza imena Giorgia Valle ostala iznimno bogata ostavština tiskovina s prijevodima i kritičkim izdanjima raznih djela antičkih pisaca. No sama sumnja ne može istovremeno biti i dokaz za tvrdnju da je Girolamo Capiduro zapravo Giorgio Valla, stoga je pitanje pravog identiteta autora komentara o djelu Rhetorica ad Herennium ponovno došlo u istraživačku sferu, i to u nedavno publiciranom radu Marije Terese Laneri. ${ }^{21}$

17 Ph. Argelati, Bibliotheca scriptorum mediolanensium, tom. 2 (pars 2), Mediolani, 1745., col. 2183, br. XVII.

18 Raccolta d'opuscoli scientifici e filologici, tom. 45, Venezia, 1751., str. 235.

19 C. Poggiali, Memorie per la storia letteraria di Piacenza, vol. 1, Piacenza, 1789., str. 144-145, br. VI.

20 V. Lancetti, Pseudonimia: ovvero, Tavole alfabetiche de' nomi finti o supposti degli scrittori con la contrapposizione de' veri, Milano, 1836., str. 54.

21 M. T. LANERI, Sull'autore del commentario In Rhetorica Ciceronis ad Herennium (Venezia 1490): Girolamo Capiduro pseudonimo di Giorgio Valla?, Rhetorica: A Journal of the History of Rhetoric, 37/3 (2019), str. 265-285. 
Problemi sjevernog Jadrana 18 (2020), str. 11-24

Nikola Cesarik Inkunabula Hieronimi Capiduri civis Parentini Georgii Vallae discipuli in Rhetorica Ciceronis ad Herennium...

Autorica je pritom detaljno prikazala problematiku vezanu za djelo Girolama Capidura, posebice analiziravši njegovu strukturu (1. predgovor iliti uvodno pismo, 2. glavni dio, odnosno komentari, 3. dodatak), nakon čega je zaključila da sami komentari i dodatak nesumnjivo pokazuju da ih je napisao upravo Giorgio Valla. ${ }^{22}$ Autorica nadalje zaključuje da je sam Valla u svojim ranijim danima napisao komentare o djelu Rhetorica ad Herennium, ali da je - očito zbog reputacije koju je uživao krajem 15. stoljeća - svoj raniji uradak odlučio sakriti iza pseudonima svojeg (vrlo vjerojatno) izmišljenog učenika. Laneri razlog takvom razvoju događaja vidi upravo u kontroverzi koja je u 15. stoljeću bila vezana za djelo Rhetorica ad Herennium, jer upravo se tada počelo sumnjati u tradicijsku predaju da je autor toga djela bio slavni Ciceron. Valla je očito bio duboko uvjeren u Ciceronovo autorstvo tog djela, no iz nekog se razloga nije htio sukobiti sa svojim suvremenicima te je djelo objavio pod pseudonimom Hijeronima Kapidura. ${ }^{23}$

A da je ta premisa točna, pokazuje činjenica da je najkasnije u studenom 1479. godine postojao rukopis s komentarima samog Giorgia Valle o djelu Rhetorica ad Herennium, jer taj se rukopis našao u kaštelu Sartirana (castello di Sartirana) nedaleko od Pavije, na popisu knjiga u vlasništvu Francesca (Cicca) Simonetta - bivšeg savjetnika i tajnika moćne obitelji Sforza - koji je netom prije bio uhićen i utamničen u Paviji. ${ }^{24}$ Dakle, s obzirom na to da je Giorgio Valla u razdobljima 1466. - 1476. te 1483. - 1485. godine držao predavanja iz retorike na Sveučilištu u Paviji, može se zaključiti da su njegovi komentari o djelu Rhetorica ad Herennium (za koje je on držao da ga je napisao Ciceron) najvjerojatnije nastali između 1466. i 1476 . godine. ${ }^{25}$

Nakon Sveučilišta u Paviji, Giorgio Valla otišao je predavati retoriku u Veneciju, ${ }^{26}$ gdje je u određenom trenutku odlučio tiskati rukopis koji je napisao u svojoj ranijoj dobi. S obzirom na to da se nije htio izlagati kritici, a time i potencijalno ugroziti reputaciju koju je uživao, Valla se očito odlučio sakriti iza pseudonima koji bi idealistički odgovarao njegovu "mlađem sebi", odnosno:

22 M. T. LANERI (nav. dj. u bilj. 21), str. 274-282.

23 M. T. LANERI (nav. dj. u bilj. 21), str. 266-267.

24 A. Giulini, La libreria d'un uomo di Stato nel Quattrocento, Archivio Storico Lombardo, 60 (1933), str. 573; M. T. LANERI (nav. dj. u bilj. 21), str. 276.

25 Rukopis s komentarima Giorgia Valle o djelu Rhetorica ad Herennium našao se i na popisu knjiga u vlasništvu Bartolomea Petronija u kolovozu 1488. godine: M. Pedralli, Novo, grande, coverto e ferrato: Gli inventari di biblioteca e la cultura a Milano nel Quattrocento, Milano: Vita e Pensiero Università, 2002., str. 166; M. T. LANERI (nav. dj. u bilj. 21), str. 276-277, bilj. 22.

26 M. T. LANERI (nav. dj. u bilj. 21), str. 276. 
teoretski bi odgovarao životnoj dobi u kojoj je sam majstor napisao komentare o djelu Rhetorica ad Herennium. No, da tom fiktivnom liku ne bi pripale sve zasluge za pisanje tog djela, Valla je lukavo napisao da Girolamo Capiduro svoje znanje, a time i sposobnost pisanja kritike tako važnog djela, ionako duguje mudrosti i učenju svojeg učitelja, odnosno samog Giorgia Valle. ${ }^{27}$

\section{Zaključak}

Nakraju, nakon što je sada jasno da valja korigirati podatke iz hrvatskih referentnih publikacija, kao što su Hrvatski biografski leksikon i Istarska enciklopedija, postavlja se pitanje treba li uopće u budućim izdanjima sličnog karaktera (ili pak novijim proširenim izdanjima istih) pronaći i mjesta za natuknicu o očito fiktivnom liku Girolama Capidura. Po mojem mišljenju, nikako ne; jer, iako je kao autor tog djela naveden Hieronymus Capidurus Parentinus, ne može se izbrisati činjenica da je pravi autor tog djela zapravo Giorgio Valla - humanist podrijetlom iz Piacenze..$^{28} \mathrm{~S}$ obzirom na to da jednokratni pseudonimi ne mogu biti nositelji samostalnih natuknica u takvim priručnicima, natuknica o Girolamu Capiduru prvenstveno bi trebala biti vezana uz Giorgia Vallu, a budući da njegov lik nema nikakve veze s hrvatskim povijesnim prostorom, njegovo se ime ne bi trebalo navoditi u priručnicima kao što su Hrvatski biografski leksikon i Istarska enciklopedija. ${ }^{29}$

$27 \quad$ Analizu predgovora, $\mathrm{s}$ originalnim latinskim tekstom i talijanskim prijevodom donosi M. T. LANERI (nav. dj. u bilj. 21), str. 271-274. Da su Vallini komentari o djelu Rhetorica ad Herennium bili poprilično prihvaćeni svjedoči činjenica da su u 16. stoljeću doživjeli više pretisaka. Tako je djelo tiskano 1514., 1546., 1550., 1554., 1557., 1564., 1565., 1568., 1569., 1570., 1571., 1578. i 1586. u Veneciji te 1541. u Baselu: M. T. LANERI (nav. dj. u bilj. 21), str. 266, bilj. 3.

28 Valja istaknuti i zanimljivo mišljenje da je Giorgio Valla svojem pseudonimu nadjenuo ime Hieronymus upravo kako bi odao poštovanje sv. Jeronimu (iliti Hijeronimu), jer upravo je taj Stridonjanin bio prvi koji je djelo Rhetorica ad Herennium pripisao slavnom govorniku Ciceronu (Hier. adv. Rufin. 1.16); usp. M. T. Laneri (nav. dj. u bilj. 21), str. 285.

29 Ovom prilikom najiskrenije zahvaljujem anonimnim recenzentima čiji su prijedlozi i kritike uvelike pridonijeli konačnoj kvaliteti ovoga rada. 


\section{Postscriptum}

Ovaj rad posvećujem pokojnom akademiku Petru Strčiću, dugogodišnjem voditelju Zavoda za povijesne i društvene znanosti HAZU u Rijeci, koji nas je napustio tijekom 2019. godine. Iako sam pokojnog akademika poznavao tijekom zadnje dvije godine njegova života, siguran sam da ću se njegova lika s radošću sjećati čitavog svojeg života. Premda su mi te nepune dvije godine bile pune raznih doživljaja s pokojnim akademikom, uvijek ću ga pamtiti kao nekog tko je doista volio svoj rodni kraj, odnosno svoju voljenu Boduliju, kako je uvijek s ponosom nazivao svoj rodni otok Krk. Dok sam pisao ovaj rad, u mislima su mi bile riječi koje je akademik često ponavljao kada bi ga iznenadile razne životne situacije, bile one pozitivne ili negativne. Tako bi često znao reći: „Život je čaroban i nikada ne znate što vas čeka sutra." $S$ obzirom na sve okolnosti, te mi se riječi čine sasvim prikladnim za zaključak ovoga rada, jer doista nisam nimalo slutio da ću se u životu ikada baviti problemom jedne inkunabule. 
Problemi sjevernog Jadrana 18 (2020), str. 11-24

Nikola Cesarik Inkunabula Hieronimi Capiduri civis Parentini Georgii Vallae discipuli in Rhetorica Ciceronis ad Herennium..

Nikola Cesarik

\section{The Incunabulum Hieronimi Capiduri civis Parentini Georgii Vallae discipuli in Rhetorica Ciceronis ad Herennium commentarium (Venetiis, 1490)}

\section{Summary}

The library of the Institute of Historical and Social Sciences of the Croatian Academy of Sciences and Arts in Rijeka has in its safekeeping a publication believed to present the incunabulum published in Venice in 1490, with commentaries by Girolamo Capiduro of Poreč (Hieronymus Capidurus Parentinus) on the work Rhetorica ad Herennium. However, since the Croatian professional literature includes information indicating Girolamo Capiduro had not published the said commentaries before 1550, doubt arose concerning the fact whether the publication kept at the Institute in Rijeka indeed was an incunabulum. The paper has questioned the state of facts and consequently proved that this publication saw the light of day in Venice in 1490. It has furthermore been proved that this was not only the only incunabulum kept at the Institute in Rijeka, but also the only known copy of this publication kept on the Croatian soil. The paper further tackles the issue of the author's identity, as all the available facts have led to the conclusion that Girolamo Capiduro, as a matter of fact, is a pseudonym of Giorgio Valla, humanist originating from Piacenza.

Keywords: incunabulum; Girolamo Capiduro; Hieronymus Capidurus Parentinus; Rhetorica ad Herennium; Cicero; pseudonym; Giorgio Valla. 